\title{
Determinants of Livelihood Strategies Among Rubber Smallholders: Case Study in Kedah Malaysia
}

\author{
Nur Hikmah Zulhaid ${ }^{1}$, Roslina Kamaruddin ${ }^{1} \&$ Siti Aznor Ahmad \\ ${ }^{1}$ School of Economics, Finance \& Banking, Northern University of Malaysia, Sintok, Kedah Malaysia \\ Correspondence: Nur Hikmah Zulhaid, School of Economics, Finance \& Banking, Northern University of \\ Malaysia, 06010 Sintok, Kedah, Malaysia. Tel: 60-1-3446-1300. E-mail: nurhikmahzulhaid@gmail.com
}

Received: November 28, 2019

Accepted: February 21, $2020 \quad$ Online Published: December 1, 2020

doi:10.5539/jsd.v14n1p1

URL: https://doi.org/10.5539/jsd.v14n1p1

\begin{abstract}
This study analyzes the determinants of alternative strategies undertaken by rubber smallholders in the state of Kedah. This study used primary data obtained through a survey of 343 smallholders using structured questionnaires in four districts. The information collected covers the demographic profiles and components of livelihood assets. Data were analyzed using one-way ANOVA and Chi-Square descriptive tests while inferential statistics were analyzed using Multinomial logit to identify determinants of strategy selection. The results showed that a majority of 44.9 percent of rubber smallholders opted for rubber and other agricultural activities while only 9.6 percent choose to use a combination of rubber and non-agricultural activities as their alternative strategies. The size of family dependence, duration of experience in agriculture, household income, technology, land size, assistance sources, gender, information sources, involvement in social associations and societies and money savings are all factors that contribute to the selection of smallholder alternative strategies. It is hoped that the government can focus on smallholder awareness measures in an effort to increase their involvement in alternative activities. Agricultural and non-agricultural activities are seen to improve the adaptive capacity of smallholders and thus increase their income.
\end{abstract}

Keywords: alternative strategy, livelihood assets, rubber smallholder, multinomial logit model, Kedah

\section{Introduction}

Kedah is one of the major agricultural states contributing to the country's rubber production. In 2012, the state's agricultural sector contributed 11.9 percent to Kedah's Gross Domestic Product (GDP). Kedah is also listed as the state with the highest rubber crop area in 2015, with the total area of 16,887 hectares (Department of Statistics Malaysia, 2017). Due to the lack the knowledge, skills and expertise among the smallholders especially in applying technology to rubber crops, productivity remains low. It can be seen from 2010 to 2016, productivity per tonne of rubber per hectare in smallholdings continued to decline (Economic Planning Unit, 2015; Department of Statistics Malaysia, 2017). The fact is that most rubber smallholders are in the low-income category and listed as poor smallholders. According to the Rubber Industry Smallholders Development Authority (RISDA) census report, in 2013, about 68 percent of rubber smallholders in Malaysia had less than RM500 a month which is lower than the Poverty Line (PGK) level for poor households of RM930 per month issued by the Economic Planning Unit for 2014. In order to reduce poverty and to continue to survive, smallholders will usually adopt alternative strategies.

One of the alternative strategies of smallholders is to expand existing activities or explore new activities aimed at improving their standard of living. However, the strategies adopted depend on accessibility of their living assets as well as their economic, social and environmental factors (Dorward et al., 2009). Diversity in crop types is often used as an alternative to maintain the livelihoods of a community, in addition to agricultural and plantation integration activities and involvement in non-agricultural activities (Legesse et al., 2013). The example of an important strategy in improving the livelihoods of smallholders is to conduct non-agricultural activities. Nonagricultural activity means any activity that is not from the agricultural sector and can provide income to households such as working in the government sector, self-employed, and off farm labor (Adams \& He, 1995).

Alternative strategies are the second best option to ensure that the smallholders have a better life and get out of the poverty line. They not only diversify their strategies for survival but also to strengthen their financial and wealth assets. The level of wealth and ownership of living assets are among the important factors in the selection of alternative strategies. With a clear understanding of the selection of strategies, the determinants of the selection of 
these rubber smallholders have rarely received the attention of researchers in general and especially in the state of Kedah. This study aims to identify the strategies of rubber smallholders in the state of Kedah and the determinants of their choice of strategies. The identification of strategies and their determinants could have implications for the policy-making of relevant parties to ensure that poverty rates among rubber smallholders are reduced and thus improve their standard of living.

\section{Methodology}

\subsection{Study Area and Sampling}

The study involved rubber smallholders in four districts in Kedah State namely Padang Terap, Baling, Pokok Sena and Pendang. Multistage sampling method was performed to select the sample in the four regions. In order to select the sample size for each district, proportionate to size sampling was performed followed by simple random sampling to select households consisting of rubber smallholders from each district through several selected dwellings. A total of 343 rubber smallholders were randomly selected from the four areas. The instruments used to obtain information are structured questionnaires that include demographic profiles and some indicators to represent living assets such as natural assets, human assets, financial assets, physical assets and social assets.

\subsection{Data Analysis}

This study uses descriptive and inferential statistical methods for data analysis tests. Chi-Square tests were used for categorical or nominal variables while ANOVA tests used continuous variables to see differences in significance in the mean values of the variables. To analyze the determinants of rubber smallholder selection strategies, Multinomial logit regression analysis is used where the selection of strategy is a dependent variable. Multinomial logit is used in this analysis because it provides more comprehensive and accurate test results than the multinomial probit which is very limited and has more complex requirements (Hausman \& Mcfadden, 1981). The dependent variables used in the model consist of four categories $[j=1, \ldots .4]$ which $j=(1)$ rubber crops only, (2) rubber crops + other agriculture, (3) rubber crops + non agriculture, (4) rubber crop + other agriculture + nonagriculture. Choice (1) of rubber crops was used as the base category in this analysis. Table 1 shows a description of the variables along with the expected results. All of these tests were analyzed through the SPSS Program 25. To confirm that there was no strong correlation between the independent variables, the Tolerance Inflation Factor (TIF) and Variance Inflation Factor (VIF) statistical tests were performed and the results showed no multicollinearity among the variables. 
Table 1. Variables definition and expected result

\begin{tabular}{|c|c|c|}
\hline Variables & $\begin{array}{l}\text { Description and measurement } \\
\text { scale }\end{array}$ & Expexted result \\
\hline \multicolumn{3}{|l|}{ Dependent variable } \\
\hline \multicolumn{3}{|l|}{$\mathrm{Y}=1$, rubber crop only } \\
\hline \multicolumn{3}{|c|}{$Y=2$, rubber crop + other agriculture } \\
\hline \multicolumn{3}{|c|}{$Y=3$, rubber crop + non agriculture } \\
\hline \multicolumn{3}{|c|}{$\begin{array}{l}\mathrm{Y}=4 \text {, rubber crop }+ \text { other agriculture }+ \\
\text { non-agriculture }\end{array}$} \\
\hline \multicolumn{3}{|l|}{ Independent variables } \\
\hline age & $\begin{array}{l}\text { Age of household head } \\
\text { (continuous) }\end{array}$ & + \\
\hline dependant & $\begin{array}{l}\text { Dependant of the household } \\
\text { (continuous) }\end{array}$ & + \\
\hline settlement & Settlement period (continuous) & + \\
\hline expAgric & $\begin{array}{l}\text { Experiences in agriculture } \\
\text { (continuous) }\end{array}$ & + \\
\hline income & $\begin{array}{l}\text { Total household income } \\
\text { (continuous in } \\
\text { Malaysia) }\end{array}$ & + \\
\hline totalinfo & $\begin{array}{l}\text { Total access to information } \\
\text { sources (continuous) }\end{array}$ & + \\
\hline totalTechno & $\begin{array}{l}\text { Total technology used by } \\
\text { household (continuous) }\end{array}$ & - \\
\hline landSize & $\begin{array}{l}\text { Total of land size (continuous in } \\
\text { hectare) }\end{array}$ & - \\
\hline gender & Gender $(0=\mathrm{P}, 1=\mathrm{L})$ & - \\
\hline edu & $\begin{array}{l}\text { Education of household head } \\
\text { (ordinal) }\end{array}$ & + \\
\hline accMarket & Access time to market(ordinal) & + \\
\hline partSociety & $\begin{array}{l}\text { Participation on other social } \\
\text { society (nominal) }\end{array}$ & + \\
\hline otherAssist & $\begin{array}{l}\text { Other assistances exclude } \\
\text { RISDA (nominal) }\end{array}$ & + \\
\hline moneySaving & Money saving (nominal) & + \\
\hline moneyBorrow & Money borrowing (nominal) & + \\
\hline
\end{tabular}

\section{Result and Discussion}

\subsection{Descriptive Analysis}

The results in Table 2 show that the majority of 44.9 percent of smallholders opt for rubber and other agricultural activities such as cash crops and vegetables and breeding. Only a small percentage of 9.6 percent chose to use a combination of rubber crops and non-agricultural activities as their alternative strategies. The second largest percentage were those who did not choose or were unable to do other activities which is 29.4 percent. This group is the only one who relies solely on rubber crops to survive. 
Table 2. Choices of livelihood strategies

\begin{tabular}{lcc}
\hline \multicolumn{1}{c}{ Strategies choices } & Frequency & Percentage (\%) \\
\hline Rubber crop only & 101 & 29.4 \\
Rubber crop + other agriculture & 154 & 44.9 \\
Rubber crop + non agriculture & 33 & 9.6 \\
Rubber crop + other agriculture + non-agriculture & 55 & 16.0 \\
\hline
\end{tabular}

Chi Square analysis was performed to see if there was a significant relationship between the two dependent and independent variables of the nominal scale and category. The variable categories of strategies include rubber only, rubber and other agriculture, rubber and non-agricultural as well as rubber, other agriculture and non-agriculture. The results of Chi-Square analysis have shown that there are several independent variables that have a significant relationship between the four categories of strategy-dependent variables. In Table 3, education, participation in social society, assistance other than RISDA, savings and money borrowing were found to be significant ( $p<0.1$ and $\mathrm{p}<0.001)$.

Table 3. Descriptive statistics for categorical variables using Chi-Square

\begin{tabular}{|c|c|c|c|c|c|c|c|c|}
\hline \multirow[b]{2}{*}{ Variables } & \multirow[b]{2}{*}{ Scale } & \multicolumn{4}{|c|}{ Livelihood strategies (\%) } & \multirow[b]{2}{*}{ Total } & \multirow[b]{2}{*}{$\chi^{2}$} & \multirow[b]{2}{*}{ P-value } \\
\hline & & $\begin{array}{c}\text { Rubber } \\
\text { crop } \\
\text { only }\end{array}$ & $\begin{array}{c}\text { Rubber } \\
\text { crop }+ \\
\text { other } \\
\text { agriculture }\end{array}$ & $\begin{array}{c}\text { Rubber } \\
\text { crop }+ \\
\text { non- } \\
\text { agriculture }\end{array}$ & $\begin{array}{c}\text { Rubber crop }+ \\
\text { other } \\
\text { agriculture }+ \\
\text { non-agriculture }\end{array}$ & & & \\
\hline gender & $\mathrm{P}$ & 35.3 & 29.9 & 51.5 & 34.5 & 34.3 & 5.727 & 0.126 \\
\hline \multirow{6}{*}{ edu } & 2 & 49.0 & 36.4 & 24.2 & 25.2 & 37.2 & & \\
\hline & 3 & 25.5 & 29.2 & 18.2 & 29.1 & 27.0 & & \\
\hline & 4 & 12.7 & 20.1 & 24.2 & 36.4 & 20.9 & & \\
\hline & 5 & 1.0 & 5.2 & 27.3 & 0.0 & 5.2 & & \\
\hline & 8 & 0.0 & 0.6 & 0.0 & 0.0 & 0.3 & & \\
\hline & 9 & 2.9 & 0.0 & 0.0 & 0.0 & 0.9 & & \\
\hline \multirow[t]{3}{*}{ accMarket } & 1 & 0 & 1.9 & 0.0 & 0.0 & 0.9 & 9.789 & 0.134 \\
\hline & 2 & 7.8 & 11.7 & 0.0 & 5.5 & 8.4 & & \\
\hline & 3 & 92.2 & 86.4 & 100.0 & 94.5 & 90.7 & & \\
\hline \multirow[t]{2}{*}{ partSociety } & $\mathrm{T}$ & 93.1 & 81.8 & 84.8 & 89.1 & 86.6 & 7.185 & $0.066^{*}$ \\
\hline & $\mathrm{Y}$ & 6.9 & 18.2 & 15.2 & 10.9 & 13.4 & & \\
\hline otherAssist & $\mathrm{T}$ & 76.5 & 90.3 & 90.9 & 78.2 & 84.3 & 11.503 & $0.009 * * *$ \\
\hline
\end{tabular}

Source: Based on the study result

Significance level at $* * * 1 \%, * * 5 \%$ and $* 10 \%$ 
Meanwhile, ANOVA tests were conducted to see mean comparisons between continuous and independent variables. Referring to the $\mathrm{F}$ value, Table 4 shows that all the independent variables differed significantly $(\mathrm{p}<0.05$ and $\mathrm{p}<0.001$ ) against the four categories of strategy choices except for the total information sources.

Table 4. Descriptive statistics for continuous variables using one-way ANOVA

\begin{tabular}{|c|c|c|c|c|c|c|c|}
\hline \multirow[b]{2}{*}{ Variables } & \multicolumn{7}{|c|}{ Livelihood strategies } \\
\hline & $\begin{array}{l}\text { Rubber } \\
\text { crop only }\end{array}$ & $\begin{array}{l}\text { Rubber crop } \\
+\quad \text { other } \\
\text { agriculture }\end{array}$ & $\begin{array}{l}\text { Rubber } \\
\text { crop } \\
\text { non- } \\
\text { agriculture }\end{array}$ & $\begin{array}{l}\text { Rubber } \\
\text { crop } \\
\text { other } \\
\text { agriculture } \\
+\quad \text { non- } \\
\text { agriculture }\end{array}$ & Total & F-value & P-value \\
\hline & & & Nilai min & & & & \\
\hline age & 56.11 & 55.32 & 50.94 & 52.51 & 54.68 & 2.69 & $0.047 * *$ \\
\hline dependant & 3.61 & 3.42 & 4.06 & 4.24 & 3.67 & 3.36 & $0.019 * *$ \\
\hline settlement & 46.87 & 42.38 & 39.30 & 40.13 & 43.04 & 3.31 & $0.020^{* *}$ \\
\hline expAgric & 26.10 & 28.76 & 20.88 & 26.58 & 26.87 & 2.91 & $0.035^{* *}$ \\
\hline income & 982.81 & 2159.94 & 2024.55 & 2828.18 & 1907.45 & 24.96 & $0.001 * * *$ \\
\hline totalInfo & 2.05 & 2.0 & 2.27 & 2.22 & 2.08 & 1.20 & 0.309 \\
\hline totalTechno & 2.92 & 4.13 & 3.82 & 3.42 & 3.63 & 7.12 & $0.001 * * *$ \\
\hline landSize & 1.186 & 1.702 & 1.304 & 1.66 & 1.51 & 9.49 & $0.001 * * *$ \\
\hline
\end{tabular}

Source: Based on the study result

Significance level at $* * * 1 \%, * * 5 \%$ and $* 10 \%$

\subsection{Determinants of Livelihood Strategies}

Table 5 shows the results of the multinomial logit analysis, that are determinants that led to the selection of livelihood strategies among rubber smallholders in Padang Terap, Baling, Pokok Sena and Pendang districts. In this analysis, rubber crop was used as a basis for comparison with the other three categories of strategies. Overall, the accuracy of this model in predicting the selection of smallholder strategies was 61.2 percent. Out of the 15,10 variables have been found to be significant in the selection of livelihood strategies among smallholders at various levels of significance. The household's dependant variable was significantly positive at the $p<0.1$ level in the selection of strategies for combination of rubber crop, other agriculture and non-agricultural activities. Assuming other factors are constant, the estimated value of the odd ratio for smallholders to choose this strategy will increase by 1.223 with a unit change in the number of dependant. This is because as the number of family members increases, the cost of living will increase. This may encourage more family members to look for other employment alternatives to supplement their income. This is in line with the study of Siti Badariah \& Mohd Rosli (2014) and Gebru, Ichoku \& Phil-Eze (2018) who stated that the number of dependants in the family influences the selection of strategies. The duration of experience in agricultural activities was also found to be significantly positive (p $<0.05$ and $\mathrm{p}<0.1$ ) in influencing smallholders to choose rubber crop and other agricultural activities as well as combinations of rubber, other agriculture and non-agricultural activities. Odds ratios indicate that, assuming other factors are constant, the probability of smallholders choosing a combination of rubber crop and other agricultural activities as well as combination of rubber crop, other agriculture and non-agricultural activities will increase by 1.033 and 1.032 as the duration of one's experience in agricultural activities increases by one year. This is because, smallholders who are more engaged in agricultural activities will usually be more open to expand their livelihood strategies in non-agricultural activities to increase income. This finding is similar to study reported by Etwire, Ramatu, Kuwornu \& Osei-Owusu (2013). In addition, total household income was found to be significantly positive in the selection of livelihood strategies in all three categories compared to rubber crop alone. With a level of significance of $p<0.001$, as income increases, the choice of strategies for these three categories will increase by an odd ratio of 1.001 and 1.002. The results of this study are in line with the findings of Sani (2016). 
Table 5. Multinomial logit model results for determinants of livelihood strategies

\begin{tabular}{|c|c|c|c|c|c|c|}
\hline & \multicolumn{2}{|c|}{$\begin{array}{l}\text { Rubber crop + other } \\
\text { agriculture }\end{array}$} & \multicolumn{2}{|c|}{ Rubber crop + non-agriculture } & \multicolumn{2}{|c|}{$\begin{array}{c}\text { Rubber crop }+ \text { other agriculture }+ \\
\text { non-agriculture }\end{array}$} \\
\hline & B & Beta Exponential & $\mathrm{B}$ & Beta Exponential & B & Beta Exponential \\
\hline age & -.034 & .966 & .006 & 1.006 & -.058 & .943 \\
\hline dependant & -.115 & .891 & .215 & 1.240 & $.201 *$ & 1.223 \\
\hline settlement & -.011 & .989 & -.008 & .992 & .000 & 1.000 \\
\hline expAgric & $\begin{array}{c}.032 \\
* *\end{array}$ & 1.033 & -.010 & .990 & $.032 *$ & 1.032 \\
\hline income & $\begin{array}{l}.001 \\
* * *\end{array}$ & 1.001 & $.002 * * *$ & 1.002 & $.002 * * *$ & 1.002 \\
\hline totalInfo & $\begin{array}{c}-.511 \\
* * *\end{array}$ & .600 & -.319 & .727 & $-.451 *$ & .637 \\
\hline totalTechno & $\begin{array}{c}.186 \\
* *\end{array}$ & 1.205 & .170 & 1.186 & -.022 & .978 \\
\hline landSize & $\begin{array}{c}.427 \\
*\end{array}$ & 1.532 & -.319 & .727 & .149 & 1.160 \\
\hline$[\mathrm{edu}=1]$ & $\begin{array}{c}16.6 \\
70\end{array}$ & 17364873.843 & 16.521 & 14967156.834 & 14.198 & 1465366.645 \\
\hline$[\mathrm{edu}=2]$ & 17.029 & 24853896.624 & 17.503 & 39960507.055 & 15.840 & 7574360.358 \\
\hline$[e d u=3]$ & 16.995 & 24030377.423 & 17.443 & 37607264.630 & 15.664 & 6353334.588 \\
\hline$[\mathrm{edu}=4]$ & 17.357 & 34528610.968 & 18.213 & 81234566.296 & 16.968 & 23390392.530 \\
\hline$[\mathrm{edu}=5]$ & 19.199 & 217793685.603 & 21.618 & 2447644147.201 & -.035 & .966 \\
\hline$[\mathrm{edu}=6]$ & 17.673 & 47330031.966 & 3.049 & 21.088 & 16.647 & 16968773.881 \\
\hline$[\mathrm{edu}=7]$ & 16.114 & 9958321.267 & 18.044 & 68581056.443 & 16.669 & 17356091.301 \\
\hline$[\mathrm{edu}=8]$ & 32.043 & $\begin{array}{c}82407742545359.2 \\
80\end{array}$ & 18.065 & 70048722.733 & 12.236 & 206095.640 \\
\hline$[\mathrm{edu}=9]$ & $0^{\mathrm{c}}$ & . & $0^{c}$ & . & $0^{c}$ & . \\
\hline [accMarket=1] & 14.120 & 1356019.298 & -3.092 & .045 & -2.719 & .066 \\
\hline [accMarket =2] & .628 & 1.874 & -15.214 & $2.470 \mathrm{E}-7$ & -.195 & .822 \\
\hline [accMarket $=3$ ] & $0^{\mathrm{c}}$ & . & $0^{\mathrm{c}}$ & . & $0^{\mathrm{c}}$ & . \\
\hline$[$ partSociety $=0]$ & $\begin{array}{l}-.968 \\
*\end{array}$ & .380 & -1.013 & .363 & -.756 & .470 \\
\hline [partSociety =1] & $0^{\mathrm{c}}$ & . & $0^{\mathrm{c}}$ & . & $0^{\mathrm{c}}$ & . \\
\hline [otherAssist $=0$ ] & $\begin{array}{c}1.509 \\
* * *\end{array}$ & 4.521 & $1.844 * *$ & 6.323 & .094 & 1.098 \\
\hline [otherAssist =1] & $0^{\mathrm{c}}$ & . & $0^{\mathrm{c}}$ & . & $0^{\mathrm{c}}$ & . \\
\hline$[$ moneySaving $=0]$ & -.132 & .876 & .293 & 1.341 & $\begin{array}{l}-1.545 \\
* *\end{array}$ & .213 \\
\hline [moneySaving =1] & $0^{\mathrm{c}}$ & . & $0^{\mathrm{c}}$ & . & $0^{\mathrm{c}}$ & . \\
\hline$[$ moneyBorrow $=0]$ & .101 & 1.107 & .083 & 1.086 & -.232 & .793 \\
\hline$[$ moneyBorrow $=1]$ & $0^{\mathrm{c}}$ & . & $0^{c}$ & . & $0^{c}$ & . \\
\hline [gender $=0$ ] & .067 & 1.069 & $1.279 * *$ & 3.593 & .112 & 1.119 \\
\hline [gender $=1$ ] & $0^{\mathrm{c}}$ & . & $0^{\mathrm{c}}$ & . & $0^{\mathrm{c}}$ & . \\
\hline
\end{tabular}

Base category: Rubber crop only

Significance level at $* * * 1 \%, * * 5 \%$ and $* 10 \%$

Total sample: 343

Pseudo R2: 0.52

Goodness of Fit (Pearson Chi-Square): 912.625, Percent correctly predicted: $61.2 \%$ 
In addition, the number of sources of information was found to be significantly negative in the selection of rubber crop and other agriculture activities as well as rubber crop, other agriculture and non-agricultural categories (p $<0.001$ and $\mathrm{p}<0.1)$. This means that as more information sources they received, their tendency to choose the strategies will decrease by the odd values of 0.600 and 0.637 . Farmers will use the information they receive only in rubber tapping activities. The results of this study are also seen in the study of Monirul Islam et al. (2013). In addition, the number of technologies was seen to be significantly positive with a $p<0.05$ level in the selection of strategy for rubber crop and other agriculture category. Assuming the other factors are constant, the ratio of the odd to the probability of an increase in the choice of the strategy is 1.205 as the number of technology increases. This reason is smallholders who adopt agricultural technologies will more focus on agricultural activities to improve the productivity. The same explanation is true in the study of Etwire, Ramatu, Kuwornu \& Osei-Owusu (2013).

The results also indicated that the total land size was significantly positive in the selection of rubber crop and other agriculture combination strategy $(\mathrm{p}<0.1)$. This result was contrary to expectations at the beginning of this study where it was expected to be significantly negative. Assuming other factors remain, the probability of smallholders choose this category strategy will increase by 1.532 as their land size increases. Generally, smallholders with larger land sizes will have better incomes. So usually they will focus more on rubber crops. But there are also smallholders who may have the initiative to earn more income by engaging in other agricultural activities as well. The results of this study are in line with the study of Nafiza \& Lu (2017). Involvement of social society was seen to give significant but negative results with a $\mathrm{p}<0.1$ level of choice in combination with rubber crop and other agriculture activities. This shows that those who are involved in social societies usually do not engage in nonagricultural activities. This is probably because most of them had joined the agricultural associations.

Assistance variable also showed significant positive effects on smallholder's involvement in rubber crop and other agriculture combination strategy as well as the combination of rubber crop and non-agricultural activities $(\mathrm{p}<0.001$ and $\mathrm{p}<0.05$ ). The likelihood of smallholders choosing these two category strategies would increase by 4.521 and 6.323 if they received a lot of assistance from other agencies besides RISDA assistance. This is because they will be more likely to expand their initiatives into agricultural and non-agricultural activities if their financial sources or equipment are better. The results of this study are in line with the findings from Sani (2016). Unexpectedly, money saving was shown to be significant negative factor in the selection of livelihood strategies $(p<0.05)$. It is found that smallholders with a lot of money saving are less likely to be involved in other agricultural and nonagricultural category strategies. They will actually focus more on getting involved in rubber crop. Gender variable in this study also contributed significantly to the selection of rubber crop and non-agricultural category. With a $\mathrm{p}$ $<0.05$ level, the probability of male smallholders preferring rubber crop and non-agricultural strategy would be greater than that of females with a mean value of 3.593. Men are more likely to participate in non-agricultural activities because of their responsibilities as heads of families to supplement their family income while women do most of the household chores. This result is in line with the study of Okonya, Syndikus, \& Kroschel (2013).

\section{Conclusion}

This study analyzes the determinants of choice of alternative strategies among rubber smallholders in four districts in Kedah. Using a sample of 343 smallholders, four categories of strategy selection were identified (1) rubber crops only; (2) rubber crops and other agriculture; (3) rubber crops and non-agricultural; (4) rubber crops, other agricultural and non-agricultural products. For most rubber smallholders in Kedah, their financial resources depend solely on rubber yields other than the financial assistance of family members. Due to the average size of the fourhectare rubber farm, the changing seasonal and climatic factors, the poor productivity of rubber, they opted for additional activities that would generate more income.

From the results of the study, it can be concluded that many smallholders choose to do other agricultural activities other than rubber tapping only to improve their standard of living which is 44.9 percent. However, there are also some farmers who are engaged in agricultural activities and are looking for alternatives to the non-agricultural activities outside the agricultural sector but the percentage is quite small ( 9.6 percent). Apparently, smallholders who are able to diversify their alternative activities are less vulnerable than those who do not. Significant factors that led to the positive selection of strategies were the amount of family dependency, duration of experience in agriculture, household total income, technology, land size, assistance other than RISDA, and gender. While the number of sources of information, involvement in social society and savings were negatively significant. Total income significantly influenced $(\mathrm{p}<0.001)$ the selection of smallholder strategies for all categories of strategies. This is because with high incomes, they are more likely to diversify their alternative activities including nonagricultural activities. 
As such, it is hoped that the government will focus on some form of settlement policy to encourage more involvement in alternative activities among the smallholders. For example, the dissemination of information could be more informal and easier for smallholders to access. This enables them to gain insight into the variety of alternative strategies available in their areas. The government's goal of targeting the smallholder's income of RM4000 a month by 2020 is expected to be realized so that they can enjoy a better life. Since involvement in social society was a significant but negative factor in the selection of alternative strategies, governments and related parties should take appropriate steps to make these smallholders more involved in various social community. This is to ensure that they are more exposed to the knowledge of doing alternative activities to supplement their income, not only in agriculture but also in non-agricultural activities. The government can also carry out awareness campaigns in money saving for sustainability over the long term. Government support for a variety of alternative activities is necessary as one of the objectives of job creation. Diversity in agricultural and non-agricultural activities is seen to improve the quality of life of smallholders and thus increase their income.

\section{Acknowledgements}

The authors wish to express their thanks to the respondents for answering the questionnaire to obtain useful inputs for this study. Many thanks to RISDA for being the leading agency in the process of collecting research data in selected districts in Kedah. Thanks are also given to the Malaysian Meteorological Department, Department of Statistics, Malaysia and related bodies for providing the required secondary data.

\section{References}

Adams, R. H., \& He, J. J. (1995). Sources of income inequality and poverty in rural Pakistan. Research Report. International Food Policy Research Institute.

Dorward, A., Anderson, S., Bernal, Y. N., Vera, E. S., Rushton, J., Pattison, J., \& Paz, R. (2009). Hanging in, stepping up and stepping out: livelihood aspirations and strategies of the poor. Development in Practice, 19(2), 240-247. https://doi.org/10.1080/09614520802689535

Etwire, P. M., Ramatu, M. A.-H., Kuwornu, J. K. M., \& Osei-Owusu, Y. (2013). Smallholder farmers' adoption of technologies for adaptation to climate change in Northern Ghana. Journal of Agricultural Extension and Rural Development, 5(6), 121-129. https://doi.org/10.5897/JAERD13.0481

Gebru, G. W., Ichoku, H. E., \& Phil-Eze, P. O. (2018). Determinants of livelihood diversification strategies in Eastern Tigray Region of Ethiopia. Agriculture and Food Security, 7(1), 1-9. https://doi.org/10.1186/s40066018-0214-0

Hausman, J. A., \& Mcfadden, D. (1981). Specification tests for the multinomial logit model. Working Paper. (No. 292).

Legesse, B., Ayele, Y., \& Bewket, W. (2013). Smallholder farmer's perception and adaptation to climate variability and climate change in Doba District, West Hararghe, Ethiopia. Asian Journal of Empirical Research, 3(3), 251-265.

Md. Monirul Islam, Sallu, S., Hubacek, K., \& Paavola, J. (2013). Vulnerability of fishery-based livelihoods to the impacts of climate variability and change: Insights from coastal Bangladesh. Regional Environmental Change, 14(1), 281-294. https://doi.org/10.1007/s10113-013-0487-6

Nafiza, S., \& Lu, Q. (2017). Household livelihood strategies choice and the impact of livestock rearing on the sustainable rural livelihoods of indigenous people in three selective districts of Bangladesh. International Research Journal of Social Sciences, 6(8), 9-22.

Okonya, J. S., Syndikus, K., \& Kroschel, J. (2013). Farmers' Perception of and Coping Strategies to Climate Change: Evidence From Six Agro-Ecological Zones of Uganda. Journal of Agricultural Science, 5(8), 252 263. https://doi.org/10.5539/jas.v5n8p252

Sani, S. (2016). Determinants of Rural Households Livelihood Strategies: Evidence from Western Ethiopia. Journal of Economics and Sustainable Development, 7(15), 103-109.

\section{Copyrights}

Copyright for this article is retained by the author(s), with first publication rights granted to the journal.

This is an open-access article distributed under the terms and conditions of the Creative Commons Attribution license (http://creativecommons.org/licenses/by/4.0/). 